\title{
Estimation of Reducing Sugar by Acid Hydrolysis of Sunflower (Helianthus annuus) Husk by Standard Methods
}

\author{
Siddegowda Chandraju1*, Rachnayak Venkatesh1, Chandraju Sadolalu Chidan Kumar², \\ Basavaraju Ajay Kumar'1 \\ ${ }^{1}$ Department of Studies in Sugar Technology and Chemistry, Sir M. Vishweshwaraya Post-Graduate Center, \\ University of Mysore, Mandya, India \\ ${ }^{2}$ Department of Engineering Chemistry, Alva's Institute of Engineering \& Technology, Shobhavana Campus, \\ Moodbidri, India \\ Email: "chandraju1@yahoo.com
}

Received 25 August 2015; accepted 24 May 2016; published 27 May 2016

Copyright (C) 2016 by authors and Scientific Research Publishing Inc.

This work is licensed under the Creative Commons Attribution International License (CC BY).

http://creativecommons.org/licenses/by/4.0/

(c) (i) Open Access

\begin{abstract}
Sunflower husk consists the primary and secondary plant nutrients-phosphorus $\left(10.94 \% \mathrm{P}_{2} \mathrm{O}_{5}\right)$, potassium $\left(25.84 \% \mathrm{~K}_{2} \mathrm{O}\right)$, calcium $(19.07 \% \mathrm{CaO})$, magnesium $(18.58 \% \mathrm{MgO})$, and also some micronutrients (zinc, copper, cobalt, manganese, iron, and molybdenum). The sunflower husk has low plasticity, and the granulation process occurs better when binding materials (sugar factory lime, molasses, urea formaldehyde resin) are used. Sun flower husk is a polysaccharide source that can be converted to reducing sugars. Sunflower husk was hydrolyzed using sulphuric acid $(0.2 \mathrm{~N})$ at a temperature of $65^{\circ} \mathrm{C}-70^{\circ} \mathrm{C}$. It was observed that the degradation has significant effect with respect to amount of husk taken and in turn sugar yield is around $40 \%-50 \%$, each of which is estimated by Bertrand's, Benedict's and Lane-Eyon method.
\end{abstract}

\section{Keywords}

Degradation, Hydrolysis, Sunflower Husk, Sugar, Estimation

\section{Introduction}

During the industrial processing of sunflowers, sunflower husks remain unused. Depending on growing condi-

\footnotetext{
${ }^{*}$ Corresponding author.
}

How to cite this paper: Chandraju, S., Venkatesh, R., Kumar, C.S.C. and Kumar, B.A. (2016) Estimation of Reducing Sugar by Acid Hydrolysis of Sunflower (Helianthus annuus) Husk by Standard Methods. Agricultural Sciences, 7, 322-325. 
tions and fertilizer as husk application, the husk contains a variety of plant nutrients and micro elements [1]. The sun flower grows in various soil conditions [2]. Sun flower husk is the outer most layer of sunflower grain. Burning of sun flower husk produced sunflower husk ash (SHA). The annual production of Sunflower Husk in India is 1.8 million metric ton and this amount is predicted to increase in the future [3].

The northern part of the state of Karnataka, India is a semi arid tropical region, well known for the production of pulses and oil seeds (sunflower). It has been reported that because of their high content of reducing sugars, it is possible to produce furfural and ethyl alcohol from sunflower hulls. As a lignocellulosic waste material, sunflower hulls was hydrolyzed with acid to yield chemical i.e. furfural [4]. The hull which is byproduct of oil extraction, contain $22 \%$ - $28 \%$ of the total weight of oilseed sunflower and may be removed before or immediately following oil extraction or may remain in the meal. Sunflower hulls contain: $4 \%$ crude protein; $5 \%$ lipid material, including wax, hydrocarbons, fatty acids, sterols, and triterpenic alcohols; 50\% carbohydrates, principally cellulose and lignin; 26\% reducing sugars, of which the majority is xylose; and $2 \%$ ash. The high fiber content and low protein and energy content of sunflower hulls reduce their nutritional value [5]. According to Badger [6] there are two types of hydrolysis i.e. enzymatic and chemical hydrolysis. Chemical hydrolysis was selected because it is relatively low cost and fast [7] [8]. The dilute acid hydrolysis of lignocelluloses biomass was run with operating condition of $0.2 \mathrm{~N}$ Sulphuric acid Concentration, $65^{\circ} \mathrm{C}-70^{\circ} \mathrm{C}$, at various amount of Sunflower husk.

\section{Materials and Methods}

The standard methods adopted for estimation are;

(i) Bertrand's method [9] is based on the reducing action of sugar on the alkaline solution of tartarate complex with cupric ion; the cuprous oxide formed is dissolved in warm acid solution of ferric alum. The ferric alum is reduced to $\mathrm{FeSO}_{4}$ which is titrated against standardized $\mathrm{KMnO}_{4}$; $\mathrm{Cu}$ equivalence is correlated with the table to get the amount of reducing sugar

(ii) In Lane-Eynon method [10] sugar solution is taken in the burette and known volume of Fehling solution is taken in conical flask. This is titrated at a temperature $65^{\circ} \mathrm{C}-70^{\circ} \mathrm{C}$. Titration is continued till it acquires a very faint blue color; add 3 drops of methylene blue indicator. The dye is reduced to a colorless compound immediately and the color changes from blue to red (at the end point).

(iii) Benedict quantitative reagent gives a visual clear end point which turns blue to white by using potassium thiocyanate which converts the red cuprous oxide to white crystals of cuprous thiocyanate, it helps in visual view [11].

The hydrolysis of sun flower husk was carried out at constant stirring using $50 \mathrm{ml}$ of $0.2 \mathrm{~N}$ sulphuric acid temperature in a hotplate, equipped with a temperature controller, and continuously shaken during the operation. Initially, $50 \mathrm{~mL}$ of $0.2 \mathrm{~N}$ sulphuric acid solution (20 mesh) sunflower husk were put into the beaker and kept under hot plate as well as the temperature controller was adjusted such that the temperature of the mixture is about $65^{\circ} \mathrm{C}-70^{\circ} \mathrm{C}$. The reaction was expected to be at constant temperature (isothermal), but before that temperature was achieved, reaction has occurred. The hydrolyzate was neutralized to bring the $\mathrm{pH}$ to 7 by the addition of calcium carbonate and activated carbon, followed by filtration. The concentration of reducing sugar was analyzed by Benedict's Bertrand's and Lane-Eynon standard procedures.

\section{Result and Discussion}

By varying the amount of sun flower husk $\left(1,2,3,4\right.$ and 5 g) respectively at constant temperature $\left(65^{\circ} \mathrm{C}-70^{\circ} \mathrm{C}\right)$ and concentration of sulphuric acid is $0.2 \mathrm{~N}$ is fixed constant. The experiment resulted in the data of reducing sugar concentrations at $3 \mathrm{~h}$ were reported below Table 1 and there corresponding data are plotted which are shown in Figures 1-3 respectively.

\section{Conclusion}

While there are some uses generally, sunflower husk is used as fuel and fertilizer, but it is still often considered a waste product in the mill and therefore often either burned in the open or dumped on wasteland. In the present work, we have applied simple hydrolysis process to obtain reducing sugar which is very good consumable source of energy and the yield percent also runs up to $40 \%$ - 50\% which is authentically reported by analytical standard procedures in an economical way. 
Table 1. Amount of reducing sugar estimated by different methods.

\begin{tabular}{cccc}
\hline Weight of sun flower husk (g) & $\begin{array}{c}\text { Sugar Estimation } \\
\text { Benedict's Method (g) }\end{array}$ & $\begin{array}{c}\text { Sugar Estimation by } \\
\text { Bertrand's Method (g) }\end{array}$ & $\begin{array}{c}\text { Sugar Estimation by } \\
\text { Lane-Eynon Method (g) }\end{array}$ \\
\hline 1.021 & 0.221 & 0.226 & 0.225 \\
2.002 & 0.446 & 0.452 & 0.438 \\
3.038 & 0.668 & 0.625 & 0.662 \\
4.021 & 0.892 & 0.815 & 0.874 \\
5.008 & 1.126 & 1.026 & 1.098 \\
\hline
\end{tabular}

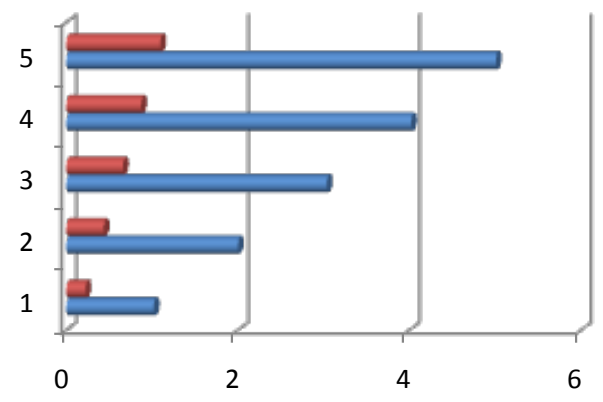

Figure 1. Estimation of reducing sugar by Benedict's method.

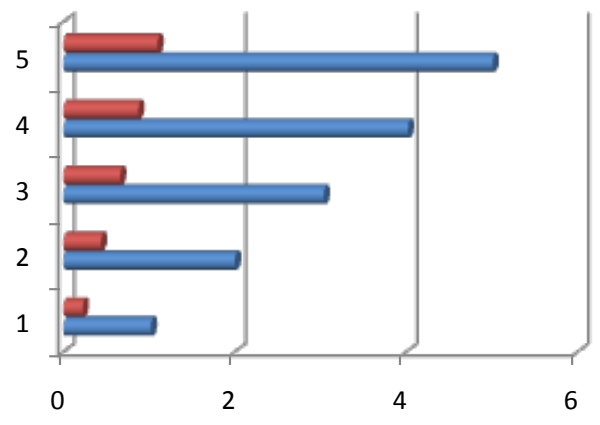

Figure 2. Estimation of reducing sugar by Bertrand's method.

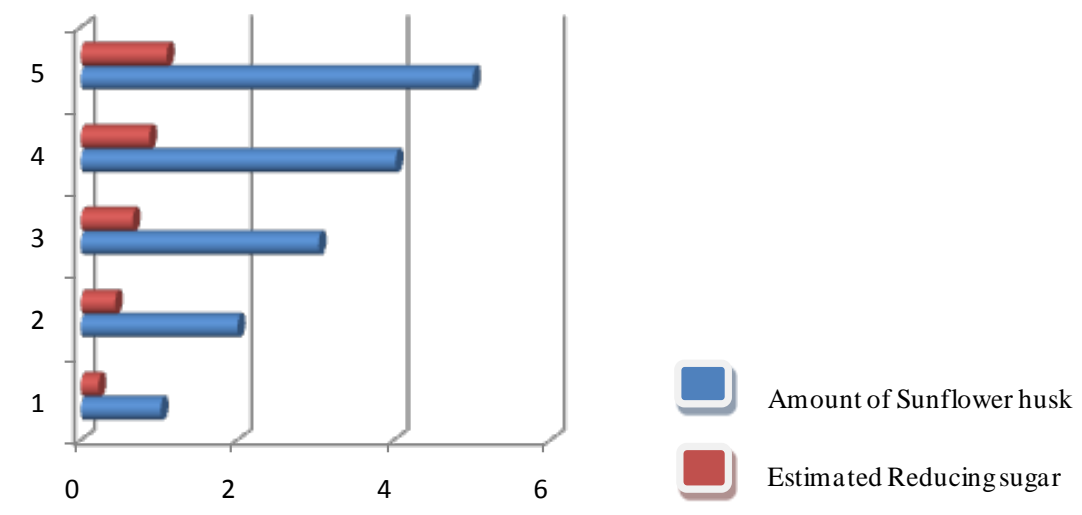

Figure 3. Estimation of reducing sugar by Lane-Eynon's method.

\section{Acknowledgements}

One of the author (R V), wish to thank UGC New Delhi and University of Mysore for providing financial support for the research work. 


\section{References}

[1] Paleckiene, R., Sviklas, A.M., Slinksiene, R. and Streimikis, V. (2010) Complex Fertilizers Produced from the Sunflower Husk Ash. Polish Journal of Environmental Studies, 19, 973-979.

[2] Maruzzo, G., Medici, F., Panei, L., Piga, L. and Rinaldi, G. (2004) Characteristics and Properties of a Mixture Containing Fly Ash, Hydrated Lime, and an Organic Additive. Environmental Engineering Science, 18, 159-165.

[3] Ambalkar, V.U. and Talib, M.I. (2012) Synthesis of Furfural from Lignocellulosic Biomass as Agricultural Residues: A Review. International Journal of Engineering and Science, 1, 30-36.

[4] Suresh, I.V., Padmakar, C., Padmakaran, P., Murty, M.V.P.L., Raju, C.B. and Vankata Rao, K. (1998) Effect of Pond Ash on Ground Water Quality: A Case Study. Environmental Management and Health, 9, 200.

[5] Zolotov, J.A. (2001) Fundamentals of Analytical Chemistry. Manual, Moscow, 464.

[6] Badger, P.C. (2002) Trends in New Crops and New Uses. ASHS Press, Alexandria, VA, 17-21.

[7] Chandraju, S., Venkatesh, R. and Chidan Kumar, C.S. (2013) Estimation of Sugars by Acid Hydrolysis of Sorghum husk by Standard Methods. Journal of Chemical and Pharmaceutical Research, 5, 1272-1275.

[8] Megawati, Sediawan, W.B., Sulistyo, H. and Hidayat, M. (2010) Pseudo-Homogeneous Kinetic of Dilute-Acid Hydrolysis of Rice Huskfor Ethanol Production: Effect of Sugar Degradation. World Academy of Science, Engineering and Technology, 41, 5-23.

[9] Chidan Kumar, C.S., Chandraju, S., Mythilya, R. and Channu, B.C. (2011) Novel Spectrophotometric Technique for the Estimation of Reducing Sugar from Wheat Husk. International Journal of Recent Scientific Research, 2, 50-53.

[10] Schneider, F (Ed.) (1979) Sugar Analysis, Official and Tentative Methods. Recommended by the ICUMSA, Peterborough, 41-73.

[11] Chandraju, S., Mythily, R. and Chidan Kumar, C.S. (2012) Estimation of Sugars by Acid Hydrolysis of Paddy Husk by Standard Methods. Journal of Chemical and Pharmaceutical Research, 4, 3588-3591. 